\title{
Survey of ripgut brome and other species on Canterbury hill/high country roadsides
}

\author{
K.N.Tozer ${ }^{1,2}$, R.H. Bryant ${ }^{2}$, C.A. Cameron ${ }^{1}$ and G.R. Edwards ${ }^{2}$ \\ ${ }^{1}$ AgResearch, Ruakura Research Centre, Hamilton 3240, New Zealand \\ ${ }^{2}$ Agriculture and Life Sciences Division, PO Box 84, Lincoln University, New Zealand \\ Corresponding author: katherine.tozer@agresearch.co.nz
}

\begin{abstract}
Ripgut brome is found in high country Canterbury pastures but little is known of its prevalence and distribution. In a $1020 \mathrm{~km}$ roadside vegetation survey, all exotic and native plant species within a $5 \mathrm{~m} \times 5 \mathrm{~m}$ quadrat were identified at $10 \mathrm{~km}$ intervals. Ripgut brome (Bromus diandrus) was present in 11\% of the 165 quadrats, which ranged from 40 to $950 \mathrm{~m}$ above sea level, occurring most frequently below $200 \mathrm{~m}$. It was least often detected adjacent to intensive pastures (only $2 \%$ of quadrats). Agrostis capillaries (browntop) was present in 63\% of quadrats, followed by Trifolium repens (white clover, 59\%) and Dactylis glomerata (cocksfoot, 53\%). The lowest number of exotic species was detected adjacent to intensive pasture (5.8) and highest adjacent to forestry ( 8.6 species). Highest numbers of native species were present adjacent to semi-improved pastures (1.7) and above $500 \mathrm{~m}$ (2.3 species). Species prevalent on roadsides were commonly grazed in hill/high country pastures rather than being pasture weeds.
\end{abstract}

Keywords annual grass, weeds, botanical survey, biodiversity.

\section{INTRODUCTION}

Bromus diandrus (ripgut brome) is an annual grass weed (Kon \& Blacklow 1988) that infests high country pastures in New Zealand. It is frequently found on north-facing slopes, sheep stock camps and sites more laxly grazed by sheep and cattle (Tozer et al. 2007). The presence of ripgut brome in livestock systems is costly, creating animal welfare issues when the large seeds $(1.5-2.5 \mathrm{~cm})$ penetrate and damage livestock carcasses, hides and fleeces (Harris \& Nowara 1995).

As a precursor to studies on the control of ripgut brome (Tozer et al. 2013), a roadside vegetation survey was undertaken in Canterbury to determine where ripgut brome occurred most frequently and identify environmental factors associated with its presence. This was to increase the understanding of ripgut brome ecology and to identify areas for potential field sites. This paper reports on the botanical composition of the roadside vegetation and the land use and altitude with which the vegetation was associated.

\section{METHODS}

A survey was undertaken between 9 and 20 February 2007, when ripgut brome was setting seed and readily identifiable, to assess the botanical composition of roadside vegetation 
in Canterbury hill/high country areas (Table 1). These back country roads, which comprised both tar-sealed and shingle roads, were selected because they passed through Canterbury hill country and enabled sampling to occur throughout Canterbury (i.e. north, central and south Canterbury). At approximately $10 \mathrm{~km}$ intervals, vascular plant species present were identified and their presence recorded in $5 \times 5 \mathrm{~m}$ quadrats, randomly positioned in the roadside vegetation adjacent to the front passenger side of the car. The quadrats were positioned such that they were equidistant between the roadside and the paddock fence. This equated to a total of 165 quadrats over a distance of $1020 \mathrm{~km}$. Sampling locations ranged in altitude from 39 to $953 \mathrm{~m}$, although only eight locations were above $690 \mathrm{~m}$ in altitude. At each sampling location the altitude and land use of the paddock adjacent to the roadside were recorded, where land use was defined as either: (a) forestry; (b) intensive pasture (dominated by sown species such as Dactylis glomerata (cocksfoot) or Lolium perenne (perennial ryegrass)); (c) semi-improved pasture (containing improved sown species such as cocksfoot or ryegrass but unproductive species such as Agrostis capillaris (browntop) were prevalent) or (d) ungrazed set-aside grassland. Each species present was assigned to a plant functional group, either annual grass, perennial grass, tussock, legume, forb or shrub, and was also classified as native or exotic. Vegetation class data were analysed using a restricted maximum likelihood (REML) approach and species presence analysed using a general linear mixed model approach, in GenStat (Version 13).

\section{RESULTS}

\section{Species presence}

Ripgut brome was observed infrequently except south of the Rakaia and Rangitata Gorges and was present in only 18 of the total 165 sites, ranging in altitude from 39 to $438 \mathrm{~m}$. This equated to $11 \%$ of the quadrats. Browntop was the most frequently observed species (present in 104 sites), followed by Trifolium repens (white clover, 97), cocksfoot (87), perennial ryegrass (72), Anthoxanthum odoratum (sweet vernal, 71), Achillea millefolium (yarrow, 62), Holcus lanatus, (Yorkshire fog, 55), Taraxacum officinale (dandelion, 54), Trifolium pratense, (red clover, 45), Discaria toumatou (matagouri, 44), Phleum pratense (timothy, 43) and Festuca spp. (fescue species, 42).

\section{Association with land use}

Of the four land uses, roadsides adjacent to ungrazed set-aside land and forestry were more likely to have ripgut brome present than roadsides adjacent to intensive pasture ( $\mathrm{P}=0.013$; Table 2 ). Roadsides adjacent to intensive pastures were most likely to have perennial ryegrass and white

Table 1 Location and length of the hill/high country Canterbury roads where roadside vegetation was sampled.

\begin{tabular}{lccc}
\hline Road location & Length surveyed & Co-ordinates (beginning) & Co-ordinates (end) \\
\hline $\begin{array}{l}\text { Darfield to Mt White Station } \\
\text { via SH73 }\end{array}$ & $120 \mathrm{~km}$ & S43 22.086 E171 58.981 & S43 03.083 E171 56.122 \\
$\begin{array}{l}\text { HakatarameaValley to north of } \\
\begin{array}{l}\text { Geraldine } \\
\text { Geraldine via SH77 to the }\end{array}\end{array}$ & $150 \mathrm{~km}$ & S44 42.916 E170 28.742 & S44 05.900 E171 11.591 \\
$\begin{array}{l}\text { Rangitata and Rakaia Gorges } \\
\text { Rakaia Gorge to Lake Lyndon }\end{array}$ & $140 \mathrm{~km}$ & S43 59.128 E171 16.762 & S43 17.970 E171 42.367 \\
$\begin{array}{l}\text { Waiau, Hanmer Springs area } \\
\text { Culverden to Amberley }\end{array}$ & $240 \mathrm{~km}$ & S43 28.601 E171 00.732 & S43 18.641 E172 00.851 \\
\hline
\end{tabular}


clover present $(\mathrm{P}<0.001)$; perennial ryegrass became increasingly scarce as land use shifted away from intensive or pastoral areas. Yarrow on the other hand, was rarely found near intensive pastures, but was often detected near forestry $(\mathrm{P}<0.05)$. Yorkshire fog was least likely to be found on roadsides adjacent to semi-improved pasture $(\mathrm{P}<0.05)$. Red clover was most likely to be present on roadsides adjacent to set-aside land $(\mathrm{P}<0.001)$. There was a tendency for matagouri to be present on roadsides adjacent to semi-improved pastures rather than on roadsides adjacent to intensive pastures $(\mathrm{P}=0.058)$.

The number of functional groups (averaging 3.3) and the frequency of tussocks, shrubs and annual grasses did not differ significantly between land use category $(\mathrm{P}>0.05)$. Forbs and exotic grasses became increasingly frequent near set-aside land and forestry areas $(\mathrm{P}<0.01)$. Native species, such as matagouri, Anthosachne spp. and Rytidosperma spp., were most frequently observed adjacent to semi-improved pastures $(\mathrm{P}<0.01$, Table 2).

\section{Association with altitude}

The number of functional groups, and the percentage of quadrats containing tussock, shrub and native species, was greatest above $500 \mathrm{~m}$ $(\mathrm{P}<0.01$; Table 2) where the lowest number of annual grass species occurred $(\mathrm{P}<0.05)$. Ripgut brome was most frequently found below $200 \mathrm{~m}$ $(\mathrm{P}<0.001)$ and declined with increasing altitude. It was never found above $500 \mathrm{~m}$, whereas browntop, sweet vernal and matagouri were found most often above $500 \mathrm{~m}(\mathrm{P}<0.05)$. There was no significant difference between altitude classes in the number of exotic species, but the number of forb species was highest below $200 \mathrm{~m}$ $(\mathrm{P}<0.05)$. There was also no significant difference between altitude classes in the percentage of quadrats containing perennial ryegrass, cocksfoot, white clover, red clover, Yorkshire fog, dandelion or yarrow.

\section{DISCUSSION}

Ripgut brome was observed infrequently on Canterbury hill/high country roadsides, being only present in $11 \%$ of quadrats. However, where observed on the roadside, the species was invariably also in adjacent pastures. Finding ripgut brome infested roadsides was therefore a useful technique to locate paddocks in which ripgut brome was present. Greater ripgut brome prevalence in roadsides adjacent to ungrazed areas (set-aside and forestry land uses) where it can readily seed, and a lesser presence in more intensively grazed areas, was also consistent with findings from subsequent surveys of high country pastures in Canterbury (Tozer et al. 2007). Intensive grazing and defoliation of reproductive stem prevents the seedheads from producing mature seed, while lax or nil grazing more readily allows seed production.

Exotic species were by far the most prevalent of all vegetation classes on roadsides. Roadsides are a key means by which weeds can be spread (Meunier \& Lavoie 2012), and may facilitate invasion of exotic species into adjacent pastures. For example, weed seeds, such as those of ripgut brome, can attach to livestock and may be dispersed into new areas or along roadsides by stock movement along back country roads. Mowing or grazing of roadsides would also facilitate ripgut brome spread. The extent to which the surveyed roadsides were mown or grazed is not known. However, occasional grazing of back country roads would be a more likely scenario than mowing.

As would be expected, there were more native species and tussocks (most of which were also native species) at higher altitudes (above $500 \mathrm{~m}$ ), which are environments generally less disturbed and less intensively farmed. However, the numbers of exotic species were not significantly different between altitude classes, demonstrating that exotic species present in New Zealand are sufficiently diverse to inhabit a range of roadside environments.

The most frequent species along roadsides in the areas surveyed was browntop (present in 104 quadrats), and four of the five most frequent species were similarly exotic grasses. Three of the five most frequent species were productive species (white clover, cocksfoot and ryegrass). 
Table 2 The percentage of quadrats in which different vegetation types and species were recorded over a range of land uses and altitudes. Numbers in parentheses are the total number of quadrats in which a species was observed. ${ }^{\star}$ denotes $\mathrm{P}<0.05,{ }^{* *} \mathrm{P}<0.01$ and ${ }^{* * *} \mathrm{P}<0.001$.

\begin{tabular}{|c|c|c|c|c|c|c|c|c|c|c|c|}
\hline & \multicolumn{5}{|c|}{ Land use } & \multicolumn{6}{|c|}{ Altitude $(\mathrm{m})$} \\
\hline & $\begin{array}{r}\text { Pasture, } \\
\text { intensive }\end{array}$ & $\begin{array}{r}\text { Pasture, } \\
\text { semi-improved }\end{array}$ & $\begin{array}{l}\text { Set- } \\
\text { aside }\end{array}$ & Forestry & LSD & $0-199$ & $200-299$ & $300-399$ & $400-499$ & $500+$ & LSD \\
\hline No. quadrats & 50 & 59 & 48 & 8 & & 25 & 43 & 31 & 33 & 29 & \\
\hline No. functional groups & 3.0 & 3.4 & 3.4 & 3.4 & 0.61 & 3.4 & 3.0 & 2.9 & 3.2 & 4.0 & $0.55^{\star \star \star}$ \\
\hline \multicolumn{12}{|c|}{ Average number of species in each quadrat } \\
\hline Tussocks & 0.1 & 0.1 & 0.1 & 0.1 & 0.19 & 0.0 & 0.0 & 0.1 & 0.1 & 0.4 & $0.17^{\star \star \star *}$ \\
\hline Forbs & 1.6 & 2.9 & 2.8 & 4.1 & $1.23^{\star *}$ & 3.8 & 2.7 & 2.4 & 2.1 & 3.4 & $1.11^{\star}$ \\
\hline Shrubs & 0.3 & 0.7 & 0.5 & 0.6 & 0.44 & 0.3 & 0.4 & 0.5 & 0.6 & 1.0 & $0.39^{\star *}$ \\
\hline Annual grasses & 0.2 & 0.5 & 0.4 & 0.8 & 0.45 & 0.8 & 0.6 & 0.4 & 0.4 & 0.1 & $0.39^{*}$ \\
\hline Native & 0.8 & 1.7 & 1.0 & 0.9 & $0.73^{\star *}$ & 0.7 & 0.5 & 0.7 & 1.3 & 2.3 & $0.66^{\star * *}$ \\
\hline Exotic & 5.8 & 7.6 & 7.9 & 8.6 & $1.97^{\star *}$ & 9.0 & 7.5 & 6.8 & 6.4 & 7.7 & 1.78 \\
\hline \multicolumn{12}{|c|}{ Percentage of quadrats in which the species was present } \\
\hline Browntop (104) & 46 & 69 & 64 & 41 & 33.8 & 25 & 51 & 44 & 71 & 82 & $32.1^{\star}$ \\
\hline White clover (97) & 87 & 45 & 44 & 50 & $31.8^{\star * *}$ & 77 & 55 & 54 & 53 & 53 & 29.3 \\
\hline Cocksfoot $(87)$ & 38 & 42 & 57 & 27 & 31.0 & 42 & 60 & 49 & 30 & 25 & 29.2 \\
\hline Perennial ryegrass $(72)$ & 72 & 36 & 31 & 17 & $35.9^{* * *}$ & 53 & 28 & 43 & 37 & 28 & 26.2 \\
\hline Sweet vernal (71) & 37 & 45 & 35 & 37 & 32.0 & 24 & 35 & 29 & 34 & 72 & $28.2^{*}$ \\
\hline Yarrow (62) & 14 & 40 & 43 & 66 & $30.7^{\star \star}$ & 64 & 42 & 29 & 26 & 35 & 28.0 \\
\hline Yorkshire fog (55) & 30 & 16 & 43 & 55 & $29.8^{*}$ & 33 & 27 & 36 & 27 & 50 & 27.1 \\
\hline Dandelion (54) & 26 & 23 & 29 & 45 & 27.3 & 50 & 33 & 39 & 37 & 7 & 28.0 \\
\hline Red clover (45) & 19 & 13 & 51 & 26 & $27.6^{\star * *}$ & 15 & 17 & 22 & 37 & 43 & 24.2 \\
\hline Matagouri (44) & 14 & 42 & 18 & 20 & 27.7 & 17 & 11 & 15 & 23 & 59 & $24.8^{\star \star}$ \\
\hline Ripgut brome (18) & 2 & 12 & 17 & 22 & $10.4^{*}$ & 29 & 15 & 10 & 3 & 0 & $15.5^{\star * *}$ \\
\hline
\end{tabular}


All of the top ten most frequent species can be grazed by livestock and none of them are considered to be pernicious weeds of pastures. Perennial ryegrass and white clover were most frequently found beside intensive pastures (indicating their ability to spread in the vicinity in which they were sown) and were unaffected by altitude, demonstrating their ability to adapt to a range of environments. Browntop, sweet vernal and matagouri were more prevalent at higher altitudes and are well adapted for high country (>500 m) environments.

In conclusion, the ten most commonly found species along Canterbury roadsides (nearly all of which were exotic) were not problem weeds but species grazed in pastures. Ripgut brome was not prevalent on inland hill/high country roadsides, but where it was found on the roadside it was always also present in the adjacent land. If roadside presence is indicative of a weed's prevalence in adjacent areas, identification of key roadside weeds could provide a useful and rapid method to identify areas in which weed control is required.

\section{ACKNOWLEDGMENTS}

Thanks to the Sustainable Farming Fund and Lincoln University for funding this project.

\section{REFERENCES}

Harris DJ, Nowara G 1995. The characteristics and causes of sheep losses in the Victorian Mallee. Australian Veterinary Journal 72: 331-340.

Kon KF, Blacklow WM 1988. Identification, distribution and population variability of great brome (Bromus diandrus Roth) and rigid brome (Bromus rigidus Roth). Australian Journal of Agricultural Research 39: 1039-1050.

Meunier G, Lavoie C 2012. Roads as corridors for invasive plant species: new evidence from smooth bedstraw (Galium mollugo). Invasive Plant Science and Management 5: 92-100.

Tozer KN, Marshall AJ, Cameron, CA, Edwards GR 2013. Salt $(\mathrm{NaCl})$ application as a tool to reduce the annual grass weed, ripgut brome, in New Zealand South Island hill/high country pastures. New Zealand Journal of Agricultural Research 56: 117-129.

Tozer KN, Marshall AJ, Sedcole JR, Edwards GR 2007. Ripgut brome (Bromus diandrus) distribution in relation to topography and management on seven high country properties in the South Island. New Zealand Plant Protection 60: 168-173. 